\title{
PENGARUH FAKTOR DEMOGRAFI DAN INVESTASI SWASTA TERHADAP PERTUMBUHAN EKONOMI KOTA SAMARINDA
}

\author{
Oleh: \\ Nurul Fitriani \\ Magister Ilmu Ekonomi Fakultas Ekonomi Universitas Mulawarman \\ Theresia Militina \\ Fakultas Ekonomi Universitas Mulawarman \\ Aji Sofyan Effendi \\ Fakultas Ekonomi Universitas Mulawarman \\ Jalan Tanah Grogot Gunung Kelua Samarinda Telepon +62541-749067
}

\begin{abstract}
Research purpose were to knowing (1) the significant effect of the rate of population growth, population density, dependency ratio, the Human Development Index (HDI) simulatneously on economic growth in Samarinda. (2) Determine the dominant effect of the rate of population growth, population density, dependency ratio, the Human Development Index (HDI) to economic growth of Samarinda. This research uses analytic descriptive with the survey method and the characteristic of research was to explain that aims to test different variables associated with research hypotheses had proposed. Results above could be explained that the population growth variable has a negatively on economic growth, which indicates the increasing population would likely reduce economic growth. Population density variable has a positive and significant impact on economic growth, which indicates that the higher the population density of an area, the higher the economic growth. Dependency ratio variable has a negative sign for economic growth, which indicates that the higher the value of the dependency ratio, the lower the economic growth. Human Development Index (HDI) has a positive and significant sign of economic growth, indicates that the higher the value of the HDI, the higher the economic growth.
\end{abstract}

Keywords: Population growth, population density, dependency ratio, the Human Development Index

\begin{abstract}
Abstrak
Tujuan yang ingin dicapai melalui penelitian ini adalah (1) Mengetahui pengaruh yang signifikan dari tingkat pertumbuhan penduduk, kepadatan penduduk, dependency ratio, Indeks Pembangunan Manusia (IPM) secara bersama-sama terhadap pertumbuhan ekonomi di Kota Samarinda. (2) Mengetahui pengaruh yang dominan dari tingkat pertumbuhan penduduk, kepadatan penduduk, dependency ratio, Indeks Pembangunan Manusia (IPM) terhadap pertumbuhan ekonomi di Kota Samarinda. Penelitian ini menggunakan metode survei deskriptif analitik dan sifat penelitian ini adalah menerangkan (explanation) yang bertujuan menguji berbagai variabel penelitian yang terkait dengan hipotesis penelitian yang diajukan. Hasil tersebut dapat dijelaskan bahwa variabel pertumbuhan penduduk mempunyai negatif terhadap pertumbuhan ekonomi, yang mengindikasikan semakin bertambah jumlah penduduk justru akan menurunkan pertumbuhan ekonomi. Variabel kepadatan penduduk mempunyai pengaruh positif dan signifikan terhadap pertumbuhan ekonomi, yang mengindikasikan semakin tinggi kepadatan penduduk suatu daerah, maka semakin tinggi pertumbuhan ekonominya. Variabel Dependency ratio mempunyai tanda negatif terhadap pertumbuhan ekonomi, yang mengindikasikan bahwa semakin
\end{abstract}


tinggi nilai dependency ratio, maka semakin rendah pertumbuhan ekonominya. Indeks Pembangunan Manusia (IPM) mempunyai tanda positif dan signifikan terhadap pertumbuhan ekonomi, mengindikasikan bahwa semakin tinggi nilai IPM, maka semakin tinggi pertumbuhan ekonominya.

Kata Kunci: Pertumbuhan penduduk, kepadatan penduduk, dependency ratio, Indeks Pembangunan Manusia

\section{PENDAHULUAN}

Sumber daya manusia dapat menentukan keberhasilan pembangunan nasional melalui jumlah dan kualitas penduduk. Jumlah penduduk yang besar merupakan pasar potensial untuk memasarkan hasil-hasil produksi, sementara kualitas penduduk menentukan seberapa besar produktivitas yang ada, namun pada kenyataannya, fenomena dilapangan malah memberikan bukti terbalik, penduduk menjadi beban Negara, khususnya di kota-kota besar di Indonesia.

Penekanan pada variabelvariabel demografi muncul sehubungan dengan kondisi demografi Indonesia yang antara lain ditandai oleh sangat timpangnya distribusi penduduk antara pulau Jawa dan daerah lainnya, tingginya beban ketergantungan usia muda serta rendahnya kualitas sumber daya manusia (Ira Setiati, 1996:48).

Penelitian ini dilakukan di Kota Samarinda pada tahun 2000-2011 karena di Kota ini terjadi fluktuasi dalam pertumbuhan ekonomi, tetapi diikuti dengan adanya kesenjangan antar wilayah, dan jika dibanding Kabupaten Kota di Indonesia lainnya, pertumbuhan ekonomi di Kota Samarinda tergolong rendah tanpa migas, proporsi dengan provinsi Kalimantan Timur, masih tergolong rendah. Namun dibanding dengan Nusa Tenggara Timur, Maluku Utara, Jambi, dan Sulawesi Tengah, Kota Samarinda lebih tinggi yang berada $6,7 \%$ tahun 2012. Selain itu, pada tahun 2008 terjadi krisis global yang diperkirakan dampaknya hampir dirasakan di seluruh dunia, termasuk Indonesia dan Kota Samarinda pada khususnya. Krisis ekonomi tersebut diperkirakan akan berdampak pada berbagai variabel, diantaranya variabel demografi, seperti jumlah tenaga kerja yang berkurang dan angka dependency ratio yang semakin tinggi.

Pertumbuhan ekonomi 4,69 persen pada tahun 2008 berasal dari peningkatan aktivitas di hampir seluruh sektor ekonomi di Kota Samarinda. 
Percepatan pertumbuhan terjadi cukup besar. PDRB dan pertumbuhan terutama di sektor Sektor Perdagangan, ekonomi dapat dilihat pada tabel 1.1. Hotel dan Restoran, serta sektor-sektor sebagai berikut : jasa lainnya dengan kontribusi yang

Tabel 1. PDRB Kota Samarinda (2000-2011)

\begin{tabular}{ccccc}
\hline \multirow{2}{*}{ Tahun } & \multicolumn{3}{c}{ PDRB (Juta Rp) } \\
& Harga Berlaku & Pertumbuhan & Harga Konstan 2000 & Pertumbuhan \\
& & $\%$ & $(4)$ & $(5)$ \\
\hline$(1)$ & $(2)$ & $(3)$ & 6.677 .497 & 6,12 \\
2000 & 6.677 .497 & & 9.293 .066 & 8,05 \\
2005 & 13.125 .820 & 115,97 & 9.803 .725 & 5,50 \\
2006 & 14.500 .247 & 10,47 & 10.094 .295 & 2,96 \\
2007 & 15.916 .600 & 9,77 & 10.567 .824 & 4,69 \\
2008 & 18.513 .118 & 16,31 & 11.098 .732 & 5,02 \\
2009 & 21.332 .456 & 15,23 & 11.768 .934 & 6,04 \\
2010 & 23.532 .439 & 10,31 & 12.423 .543 & 5,56 \\
$2011^{\mathrm{r}}$ & 24.975 .765 & 6,13 & & \\
& & & &
\end{tabular}

Sumber: RKPD Kota Samarinda, 2012

Dengan kondisi tersebut, maka penurunan yang terjadi di sektor Industri Pengolahan tidak memberikan dampak secara signifikan pada perekonomian secara total. Hal ini ditunjukkan oleh percepatan yang tetap terjadi di wilayah Kota Samarinda. Pada tahun 2005, besaran nilai PDRB atas dasar harga berlaku sebesar 13,13 trilyun rupiah atau lebih dari dua kali lipat PDRB di tahun 2000, sebesar 6,08 trilyun rupiah. Kenaikan pada nilai PDRB atas dasar harga berlaku berlanjut hingga tahun 2008 nilainya mencapai 18,51 trilyun rupiah atau sekitar tiga kali lipat dibandingkan nilai PDRB di tahun 2000, yaitu sebesar 6,08 trilyun rupiah. Hal ini menunjukkan adanya pertumbuhan ekonomi yang konsisten selama kurun waktu 9 (sembilan) tahun terakhir.

Kualitas sumber daya manusia dapat mempengaruhi faktor-faktor penentu pertumbuhan ekonomi (Aditia, 2010). Pertumbuhan penduduk hanya akan meningkatkan kuantitas sumber daya manusia tanpa melihat kualitasnya. Oleh karena itu pertambahan kuantitas harus diikuti oleh peningkatan kualitas sumber daya manusia itu sendiri. Sumber daya manusia yang berkualitas akan mampu memberikan kontribusi dalam kemajuan teknologi yang lebih mutakhir secara cepat, dan teknologi tersebut akan lebih mudah untuk diterapkan kepada penduduk luas 
apabila penduduknya memiliki pengetahuan dasar yang cukup sehingga lebih mudah menyerap informasi.

Ukuran kualitas hidup adalah Indeks Pembangunan Manusia (IPM) dibangun melalui pendekatan tiga dimensi dasar. Dimensi tersebut mencakup umur panjang dan sehat; pengetahuan dan kehidupan yang layak . untuk mengukur dimensi kesehatan, digunakan angka harapan hidup. Selanjutnya untuk mengukur dimensi pengetahuan digunakan indikator angka melek huruf dan rata-rata lama sekolah yang dikombinasikan. Dan untuk mengukur dimensi hidup layak digunakan indikator kemampuan daya beli (Purchasing Power Parity).

Fenomena dilapangan, khususnya di Kota Samarinda, faktor penduduk sangat berpengaruh terhadap ekonomi. Beberapa hal yang berhubungan dengan pertumbuhan ekonomi antara lain adalah pertumbuhan penduduk, kepadatan penduduk, rasio ketergantungan, dan Indek Pembangunan Manusia.

Pertumbuhan penduduk dipengaruhi oleh fertilitas, mortalitas dan migrasi. Tingkat fertilitas yang tinggi memacu pertumbuhan penduduk secara cepat, dan dalam jangka panjang dapat menciptakan tenaga kerja yang dapat membantu pertumbuhan ekonomi, jika selama masa tunggu jangka panjang tersebut calon tenaga kerja mendapat pendidikan dan ketrampilan yang baik sehingga kualitas sumber daya manusianya baik. Sebaliknya, jika tingkat fertilitas rendah maka tenaga kerja produktif yang diharapkan akan membantu peningkatan pertumbuhan ekonomi pun menjadi tidak tersedia, dan berpengaruh tidak baik bagi pertumbuhan ekonomi.

Kualitas sumber daya manusia juga dapat menjadi faktor penyebab terjadinya penduduk miskin. Kualitas sumber daya manusia dapat dilihat dari indeks kualitas hidup/indeks pembangunan manusia. Rendahnya Indeks Pembangunan Manusia (IPM) akan berakibat pada rendahnya produktivitas kerja dari penduduk. Produktivitas yang rendah berakibat pada rendahnya perolehan pendapatan. Sehingga dengan rendahnya pendapatan menyebabkan tingginya jumlah penduduk miskin dan rendahnya pertumbuhan ekonomi.

Berdasarkan pada fenomena dan uraian pada latar belakang di atas, bagaimana faktor kependudukan memberikan dampak terhadap ekonomi 
daerah, maka penelitian ini menganalisis pengaruh yang signifikan dari tingkat pertumbuhan penduduk, kepadatan penduduk, dependency ratio, Indeks Pembangunan Manusia (IPM) secara bersama-sama terhadap pertumbuhan ekonomi di Kota Samarinda.

Pertumbuhan Ekonomi adalah kenaikan kapasitas dalam jangka panjang dari negara yang bersangkutan untuk menyediakan berbagai barang ekonomi kepada penduduknya. Kenaikan kapasitas itu sendiri ditentukan oleh adanya kemajuan atau penyesuaian teknologi, institusional (kelembagaan), dan ideologi terhadap berbagai tuntutan keadaan yang ada.

Teori Pertumbuhan Ekonomi Klasik adalah pertumbuhan ekonomi bergantung pada faktor-faktor produksi. Laju pertumbuhan ekonomi sangat dipengaruhi oleh produktivitas sektorsektor dalam menggunakan faktorfaktor produksinya. Produktivitas dapat ditingkatkan melalui berbagai sarana pendidikan, pelatihan dan manajemen yang lebih baik.

Teori Pertumbuhan Ekonomi Neo-Klasik adalah sebagai kenaikan jangka panjang dalam kemampuan suatu negara untuk menyediakan semakin banyak jenis barang-barang ekonomi kepada penduduknya, kemampuan ini tumbuh sesuai dengan kemajuan tekhnologi, dan penyesuaian kelembagaan dan ideologis yang diperlukannya.

Adapun demografi berasal dari bahasa Yunani yang merupakan gabungan dua kata, yaitu demos dan grafein yang artinya rakyat dan tulisan. Jadi demografi adalah setiap tulisan mengenai rakyat atau penduduk.

Dikalangan para pakar pembangunan telah ada konsensus bahwa laju pertumbuhan penduduk yang tinggi tidak hanya berdampak buruk terhadap suplai bahan pangan, namun juga semakin membuat kendala bagi pengembangan tabungan, cadangan devisa, dan sumberdaya manusia.

\section{Pendidikan}

Menjadi penting bagi kita untuk memahami bahwa kemiskinan bisa mengakibatkan kebodohan,dan kebodohan jelas identik dengan kemiskinan. Untuk memutus rantai sebab akibat diatas, ada satu unsur kunci yaitu pendidikan. Karena pendidikan adalah sarana menghapus kebodohan sekaligus kemiskinan.

Indeks Pembangunan Manusia 
Indeks Pembangunan Manusia (IPM), secara khusus mengukur capaian pembanguanan manusia menggunakan beberapa komponen dasar kualitas hidup. IPM dihitung berdasarkan data yang dapat menggambarkan ke empat komponen; yaitu capaian umur panjang dan sehat yang mewakili bidang kesehatan; angka melek huruf, partisipasi sekolah dan rata-rata lamanya bersekolah mengukur kinerja pembangunan bidang pendidikan; dan kemampuan daya beli masyarakat terhadap sejumlah kebutuhan pokok yang dilihat dari rata-rata besarnya pengeluaran per kapita sebagai pendekatan pendapatan.

Untuk dapat menganalisis pertumbuhan ekonomi di Kota Samarinda, kita dapat melihat faktorfaktor yang mempengaruhi pertumbuhan ekonomi yaitu IPM, kepadatan penduduk dan rasio ketergantungan penduduk. Secara skema kerangka pemikiran dapat digambarkan sebagai berikut :

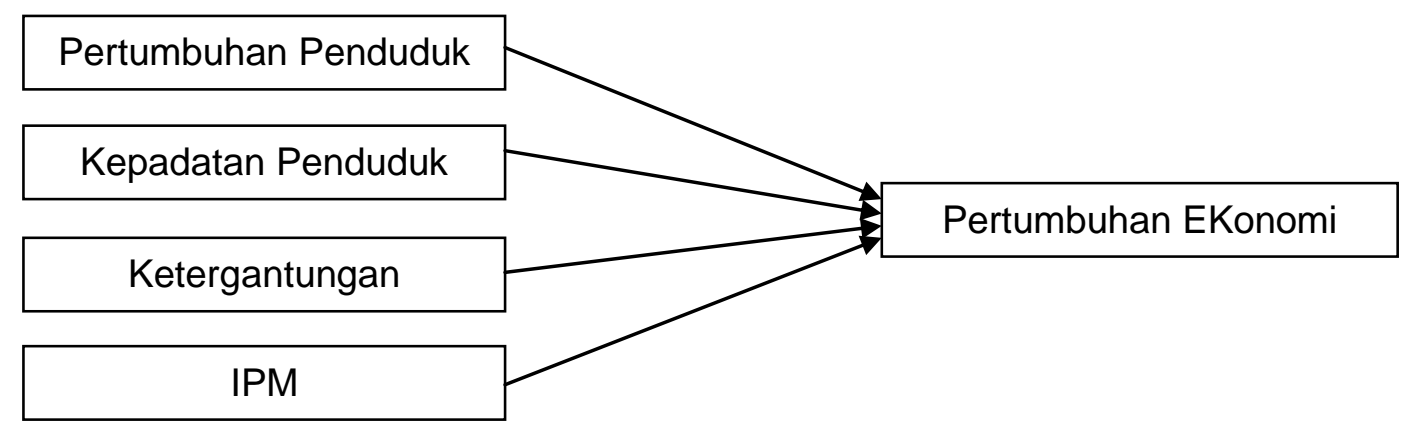

Gambar 1. Kerangka Konsep Penelitian

Berdasarkan rumusan masalah dan teori yang telah diuraikan, maka diajukan hipotesis sebagai berikut:

1)Tingkat pertumbuhan penduduk, kepadatan penduduk, dependency ratio, dan Indeks Pembangunan Manusia (IPM), bersama-sama berpengaruh signifikan terhadap pertumbuhan ekonomi di Kota Samarinda.

2)Indeks Pembangunan Manusia (IPM) merupakan faktor yang berpengaruh dominan terhadap pertumbuhan ekonomi di Kota Samarinda.

\section{METODE PENELITIAN}

Langkah berikutnya adalah menspesifikasikan variabel-variabel penelitian dan melakukan pendefinisian secara operasional. Hal ini bertujuan agar variabel penelitian yang telah ditetapkan dapat dioperasionalkan, 
sehingga memberikan petunjuk tentang bagian suatu variabel dapat diukur.

Jenis data yang digunakan dalam penelitian ini adalah data time series tahun 2000 - 2011 yang berhubungan Metode analisis data yang digunakan dalam penelitian ini adalah model data time series, yang memiliki observasi-observasi pada suatu unit analisis pada suatu titik waktu tertentu. Data silang tempat tersebut digunakan untuk mengetahui pengaruh variabel variabel Tingkat Pertumbuhan Penduduk, variabel Kepadatan Penduduk, Dependency Ratio dan IPM, terhadap laju pertumbuhan ekonomi.

Model fungsi yang akan digunakan untuk mengetahui pertumbuhan ekonomi di Kota Samarinda yaitu:

$$
\begin{aligned}
\mathbf{Y}_{\mathbf{t}}= & \boldsymbol{\beta}_{\mathbf{0}}+\boldsymbol{\beta}_{\mathbf{1}} \mathbf{X}_{\mathbf{1}}+\boldsymbol{\beta}_{\mathbf{2}} \mathbf{X}_{\mathbf{2}}+\boldsymbol{\beta}_{\mathbf{3}} \mathbf{X}_{\mathbf{3}}+\boldsymbol{\beta}_{\mathbf{4}} \mathbf{X}_{\mathbf{4}}+ \\
& \mathbf{e} \ldots . . \text { Hartono }(2007 ; 67) \\
\mathrm{Y}_{\mathrm{t}}= & \text { Pertumbuhan Ekonomi } \\
\mathrm{X}_{1}= & \text { Pertumbuhan Penduduk } \\
\mathrm{X}_{2}= & \text { Kepadatan Penduduk } \\
\mathrm{X}_{3}= & \text { Dependency Ratio } \\
\mathrm{X}_{4}= & \text { Indeks Pembangunan Manusia } \\
\mathrm{e}= & \text { error Term }
\end{aligned}
$$

Pengaruh variabel independent terhadap variabel dependen secara bersama-sama, menggunakan uji $\mathrm{F}$ dengan variable PDRB, Penduduk dan IPM. Data ini diperoleh dari Badan Pusat Statistik Kota Samarinda dan Badan Perencanaan dan Pembangunan Daerah Kota Samarinda dengan membuat hipotesis sebagai berikut:

H0 diterima jika: $\beta 1=\beta 2=\beta 3=\beta 3=0$, artinya variabel independen faktor demografi secara bersama-sama tidak berpengaruh terhadap pertumbuhan ekonomi.

Ha diterima jika: $\beta 1=\beta 2=\beta 3=\beta 3$ $\neq 0$, artinya variabel independen faktor demografi secara bersama-sama berpengaruh terhadap pertumbuhan ekonomi.

Uji $\mathrm{t}$ dilakukan untuk mengetahui pengaruh variabel independen secara individual terhadap variabel dependennya (pertumbuhan ekonomi). Hipotesis yang diajukan yaitu:

H0 diterima jika: $\beta \mathrm{i}=0$, artinya variabel independen faktor demografi tidak berpengaruh terhadap pertumbuhan ekonomi.

Ha diterima jika: $\beta \mathbf{i} \neq 0$,artinya variabel independen faktor demografi berpengaruh terhadap pertumbuhan ekonomi. 
Pengujian Asumsi Klasik

Persamaan yang diperoleh dari sebuah estimasi dapat dioperasikan secara statistik jika memenuhi asumsi klasik, yaitu memenuhi asumsi bebas multikolinearitas, heteroskesidasitas, autokorelasi, serta disturbance term terdistribusi secara normal. Pengujian asumsi klasik ini dilakukan dengan bantuan software SPSS 15.

\section{PEMBAHASAN}

Dalam penelitian ini untuk menguji ada tidaknya multikolinearitas dilihat dari perbandingan antara nilai $\mathrm{R}$ regresi parsial (auxiliary regression) dengan nilai $\mathrm{R}^{2}$ regresi utama. Apabila nilai regresi parsial (auxiliary regression) lebih besar dibandingkan nilai $\mathrm{R}^{2}$ utama, maka dapat disimpulkan bahwa dalam persamaan tersebut terjadi multikolinearitas. $\quad$ Tabel 4.6 menunjukkan perbandingan antara nilai $\mathrm{R}$ parsial (auxiliary regression) dengan nilai $\mathrm{R}^{2}$ regresi utama.

Tabel 2. Perbandingan antara nilai $\mathrm{R}$ regresi parsial (auxiliary regression) dengan nilai $\mathrm{R}^{2}$ regresi utama

\begin{tabular}{clcc}
\hline No. & Persamaan & $\begin{array}{c}\text { R-Square }\left(\mathbf{R}^{2}\right) \\
\text { Auxiliary Regression }\end{array}$ & $\begin{array}{c}\text { R-Square }\left(\mathbf{R}^{2}\right) \\
\text { Main Regression }\end{array}$ \\
\hline 1. & $\mathrm{Y}=\mathrm{a}+\mathrm{b}_{1} \mathrm{X}_{1}+\mathrm{e}$ & 0,423 & 0,774 \\
2. & $\mathrm{Y}=\mathrm{a}+\mathrm{b}_{2} \mathrm{X}_{2}+\mathrm{e}$ & 0,672 & 0,774 \\
3. & $\mathrm{Y}=\mathrm{a}+\mathrm{b}_{3} \mathrm{X}_{3}+\mathrm{e}$ & 0,653 & 0,774 \\
4. & $\mathrm{Y}=\mathrm{a}+\mathrm{b}_{4} \mathrm{X}_{4}+\mathrm{e}$ & 0,279 & 0,774 \\
\hline
\end{tabular}

Sumber: Hasil analisis output SPSS

Tabel 2. menunjukkan bahwa model persamaan pengaruh pertumbuhan penduduk, kepadatan penduduk, dependency ratio dan IPM terhadap pertumbuhan ekonomi di Kota Samarinda tahun 2000-2011 tidak mengandung multikolinearitas karena tidak ada nilai $\mathrm{R}^{2}$ (auxiliary regression) yang lebih besar dibandingkan nilai $\mathrm{R}^{2}$ Regresi Utama.

Uji asumsi multikolonieritas juga dilakukan dengan uji nilai "Variance Inflation Factor" (VIF), yaitu jika nilai (VIF < 5), yang berarti tidak terjadi multikoliniaritas antar variabel bebas, berikut ini VIF 4 variabel bebas. Berdasarkan hasil tersebut, semua variabel bebas memiliki nilai VIF di bawah $5\left(\mathrm{VIF}_{\mathrm{k}}<5\right)$, dengan demikian bahwa model tersebut bebas dari gejala Multikolonearitas.

Analisis uji autokorelasi berdasarkan tabel Durbit Watson, menghasilkan angka sebesar 1,634, berdasarkan kriteria autokorelasi terdekat dalam interval 2,34 - 2,92 yang berarti Tidak ada Kesimpulan. 
Tabel 3. Kriteria Autokorelasi

\begin{tabular}{cl}
\hline Durbit Watson & \multicolumn{1}{c}{ Kesimpulan } \\
\hline Kurang dari 1,08 & Ada Autokorelasi \\
$1,08-1,66$ & Tanpa Kesimpulan \\
$1,66-2,34$ & Tidak ada Auto Korelasi \\
$2,34-2,92$ & Tanpa Kesimpulan \\
Lebih dari 2,92 & Ada Autokorelasi \\
\hline
\end{tabular}

Sumber: Hasil analisis output SPSS

Koefisien determinasi (R- independen dalam menjelaskan variasi Square $=\mathrm{R}^{2}$ ) pada intinya mengukur variabel dependen amat terbatas. Nilai seberapa jauh kemampuan model dalam yang mendekati satu berarti variabelmenerangkan variasi variabel dependen. variabel independen memberikan Nilai koefisien determinasi adalah nol hampir semua informasi yang dan satu. Nilai $\mathrm{R}^{2}$ yang kecil berarti dibutuhkan untuk memprediksi variasi kemampuan variabel-variabel variabel dependen.

Tabel 4. Model Regresi: Koefisien Determinasi dan Uji F

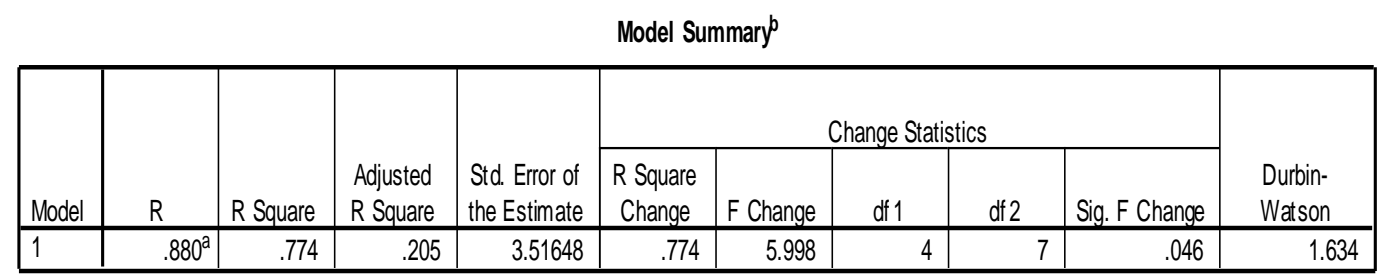

a. Predictors: (Constant), IPM, DR, Pert. Penduduk, Kepadatan

b. Dependent Variable: Pert. Ekonomi

Sumber: Hasil analisis output SPSS

Regresi pengaruh pertumbuhan penduduk, kepadatan penduduk dependency ratio dan IPM terhadap pertumbuhan ekonomi di Kota Samarinda, dengan $\mathrm{a}=5$ persen dan degree of freedom $(\mathrm{df})=7(\mathrm{n}-\mathrm{k}-1=12$ 4-1), maka diperoleh nilai t-tabel sebesar 2,365. Tabel 4 menujukkan hasil regresi pengaruh pertumbuhan penduduk, kepadatan penduduk dependency ratio dan IPM terhadap pertumbuhan ekonomi di Kota Samarinda, dapat disimpulkan bahwa pada taraf 95 persen $(\mathrm{a}=5$ persen) variabel IPM (Indeks Pembangunan Manusia) dan DE (Kepadatan Penduduk) berpengaruh signifikan secara statistik terhadap variabel pertumbuhan ekonomi. 
Tabel 5. Koefisien Regresi dan Uji Secara Pasrtial

\begin{tabular}{|c|c|c|c|c|c|c|c|c|}
\hline \multicolumn{9}{|c|}{ Coefficients } \\
\hline \multirow{2}{*}{\multicolumn{2}{|c|}{ Model }} & \multicolumn{2}{|c|}{$\begin{array}{l}\text { Unstandardized } \\
\text { Coeff icients }\end{array}$} & \multirow{2}{*}{$\begin{array}{c}\text { Standardized } \\
\text { Coeff icients } \\
\text { Beta }\end{array}$} & \multirow[b]{2}{*}{$t$} & \multirow[b]{2}{*}{ Sig. } & \multicolumn{2}{|c|}{ Collinearity Statistics } \\
\hline & & $\mathrm{B}$ & Std. Error & & & & Tolerance & VIF \\
\hline \multirow[t]{5}{*}{1} & (Constant) & 176.385 & 383.785 & & .460 & .660 & & \\
\hline & Pert. Penduduk & -.305 & .341 & -.438 & -.895 & .400 & .419 & 2.388 \\
\hline & Kepadatan & .088 & .020 & 1.111 & 4.373 & .017 & .233 & 4.262 \\
\hline & DR & -.273 & 1.107 & .094 & -.247 & .812 & .696 & 1.436 \\
\hline & IPM & 2.486 & .510 & 1.158 & 4.871 & .013 & .278 & 3.599 \\
\hline
\end{tabular}

a. Dependent Variable: Pert. Ekonomi

Sumber: Hasil analisis output SPSS

Dalam regresi pengaruh Pertumbuhan penduduk, kepadatan penduduk, dependency ratio dan Indeks Pembangunan Manusia (IPM) terhadap pertumbuhan ekonomi di Kota Samarinda, dengan menggunakan metode Ordinary Least Square (OLS), diperoleh nilai koefisien regresi untuk setiap variabel dalam penelitian dengan persamaan sebagai berikut :

$$
\begin{aligned}
Y_{t}= & \beta_{0}+\beta_{1} X_{1}+\beta_{2} X_{2}+\beta_{3} X_{3}+\beta_{4} X_{4}+e \\
Y_{t}= & 176,385-0,305 X_{1}+0,088 X_{2}- \\
& 0,273 X_{3}+2,486 X_{4}+e
\end{aligned}
$$

Tidak signifikannya pertumbuhan penduduk dapat disebabkan oleh beban ketergantungan kota masih berat untuk menampung pertumbuhan penduduk yang relatif tinggi, oleh sebab itu walaupun pertumbuhan penduduk tinggi, tidak terlalu mempengaruhi pertumbuhan ekonomi di Kota Samarinda.

Hasil penelitian menunjukkan bahwa pertumbuhan penduduk memberikan pengaruh negatif dan tidak signifikan terhadap pertumbuhan ekonomi di Kota Samarinda, kenyataanya di kota Samarinda pada kawasan padat penduduk seperti Samarinda Utara, Samarinda Ulu dan Samarinda Ilir, pertumbuhan penduduk diiringi dengan pertumbuhan investasi yang cukup baik, sehingga pertumbuhan penduduk baik berasal dari imigrasi maupun kelahiran, akan mampu ditopang dengan investasi yang tinggi pula. Kota Samarinda juga menggambarkan berbagai dinamika yang terjadi di masyarakat, baik secara sosial maupun kultural. Menurunnya tingkat kelahiran (fertilitas) dan tingkat kematian (mortalitas), meningkatnya arus perpindahan antar daerah (migrasi) dan proses urbanisasi, termasuk arus ulang alik (commuters), juga mempengaruhi kebijakan kependudukan yang diterapkan. Menurut data Dinas Kependudukan dan 
Catatan Sipil Kota Samarinda, Jumlah

Penduduk Kota Samarinda tahun 2011 sebanyak 872.854 jiwa, terdiri dari 391.184 perempuan dan 358.243 lakilaki, ini menggambarkan pertumbuhan rata-rata $6,14 \%$ setiap tahun.

Dari hasil regresi ditemukan bahwa indeks pembangunan manusia (IPM) memberikan pengaruh yang positif dan signifikan terhadap Studi ini menganalisis bagaimana pengaruh variabel Pertumbuhan penduduk, kepadatan penduduk, dependency ratio dan IPM terhadap pertumbuhan ekonomi Kota Samarinda. Berdasarkan uraian hasil analisis pada bab-bab sebelumnya, maka dapat ditarik kesimpulan sebagai berikut:

Pengaruh variabel pertumbuhan penduduk mempunyai tanda negatif terhadap pertumbuhan ekonomi, artinya semakin bertambah jumlah penduduk justru akan menurunkan pertumbuhan ekonomi. Pertumbuhan penduduk yang tinggi akan dibutuhkan untuk membuat konsumsi dimasa mendatang semakin tinggi, kemudian pertumbuhan penduduk yang cepat membuat semakin sulit melakukan perubahan yang pertumbuhan ekonomi di Kota Samarinda. Kenaikan IPM sebesar 1 persen akan menyebabkan kenaikan pertumbuhan ekonomi sebesar 2,486 persen. Hal itu dikarenakan indeks pembangunan manusia (IPM) sebagai salah satu representasi dari human capital.

\section{PENUTUP}

dibutuhkan untuk meningkatkan perubahan ekonomi dan sosial.

Variabel kepadatan penduduk mempunyai tanda positif dan signifikan terhadap pertumbuhan ekonomi, artinya semakin tinggi kepadatan penduduk suatu daerah, maka semakin tinggi pertumbuhan ekonominya.

Variabel Dependency ratio mempunyai tanda negatif terhadap pertumbuhan ekonomi, artinya bahwa semakin tinggi nilai dependency ratio, maka semakin rendah pertumbuhan ekonominya.

Indeks Pembangunan Manusia (IPM) mempunyai tanda positif dan signifikan terhadap pertumbuhan ekonomi, artinya semakin tinggi nilai IPM, maka semakin tinggi pertumbuhan ekonominya. 


\section{DAFTAR PUSTAKA}

Arsyad, Lincolin. 1999. Ekonomi Pembangunan. Edisi Keempat. Yogyakarta : Bagian Penerbitan STIE YKPN.

Arsyad, Lincolin. 2006. Ekonomi Pembangunan. Edisi Ketujuh. Yogyakarta : Bagian Penerbitan STIE YKPN.

Bun Song Lee. Shuanglin Lin. "Government Size. Demographic Changes. and Economic Growth." International Economic Journal. vol 8. 1994. hal. 93- 95. Gujarati.

Erlangga .2004. Pembangunan Ekonomi di Dunia Ketiga. Edisi kedelapan. Jakarta : Penertbit Erlangga.

Ghozali, Imam. 2005. Aplikasi Analisis Multivariate Dengan Program SPSS. BP Undip

Gujarati, Damodar.1997. Ekonometrika Dasar. Alih Bahasa Sumarmo Zain. Jakarta : Erlangga.

Hartono, Jogiyanto. 2007 Metodologi Penelitian Bisnis, Salah Kaprah dan Pengalaman-Pengalaman, BPFE Universitas Gadjah Mada, Jogjakarta.

Iskandar, N.1981. Dasar-dasar Demografi. FE-UI.Jakarta.

Jhingan, M.L.1988. Ekonomi Pembangunan dan Perencanaan. Alih Bahasa D. Guritno. Jakarta : Rajawali Pers

Kelly. Allen C. 1976. Demographic Change and the Size of the Government Sector. Southern Economic Journal. Hal. 1056-1066

Kristiana, Peby.2008. Analisis Pengaruh Faktor-faktor Demografi Terhadap Pertumbuhan Ekonomi Di Kabupaten Cianjur Periode 19832007.Skripsi

Tidak
Dipublikasikan.Fakultas Ekonomi Undip. Semarang.

Kuncoro, Mudradjad. 2004. Adakah Perubahan Konsentrasi Spasial Industri Manufaktur di Indonesia, 1976-2001?. Jurnal Ekonomi dan Bisnis, Vol.19 No.4, Oktober 2004. 1997, Ekonomi Pembangunan : Teori, Masalah dan Kebijakan, UPP AMP YKPN, Yogyakarta.

Mantra, Ida Bagoes. 2000. Demografi Umum. Edisi Kedua. Yogyakarta : Pustaka Pelajar

Marzuki, 2005, Metodologi Riset, Ekonisia Kampus Fakultas Ekonomi UII, Yogyakarta.

Nazir, Moh. 1988. Metode Penelitian. Jakarta : Ghalia Indonesia

Pancawati, Neni. 2000. Pengaruh Rasio Kapital-Tenaga Kerja, Tingkat Pendidikan, Stok Kapital dan Pertumbuhan Penduduk Terhadap Tingkat Pertumbuhan GDP Indonesia. Jurnal Ekonomi dan Bisnis Indonesia, Vol.15, No.2

Santosa, Heru. 2005, Analisis Pertumbuhan Ekonomi Kota Semarang dan Kabupaten Blora Propinsi Jawa Tengah, Tesis, Program Pasca Sarjana MIEP, Universitas Diponegoro, Semarang (Tidak Dipublikasikan)

Setiati, Ira.1996. Pengaruh Penggunaan Variabel Demografi Dalam Model Pertumbuhan Ekonomi kasus 25 Provinsi di Indonesia (1983-1992). Jurnal Ekonomi dan Keuangan Indonesia. Vol XLIV No.2

Sihombing, Kartini. 2008. Pengaruh Aglomerasi. Modal. Tenaga Kerja. dan Kepadatan Penduduk Terhadap Pertumbuhan Ekonomi Kabupaten Demak. Skripsi Tidak Dipublikasikan. Fakultas Ekonomi Undip. Semarang

Simanjuntak, Payaman. 1985. Pengantar Ekonomi Sumber Daya Manusia. Jakarta : LPFE UI. 
Subri, Mulyadi. 2003.Ekonomi Sumber Daya Manusia. Jakarta : PT Grafindo.

Sukirno, Sadono. 1981. Pengantar Teori Makroekonomi. Jakarta : Bina Grafika.

1997. Pengantar Ekonomi Makro. Edisi Kedua. Jakarta : Grafindo Persada.

2003. Pengantar Teori Makroekonom. Jakarta : Raja Grafindo Persada.
Suparmoko, M..1998. Pengantar Ekonomika Makro. Edisi Keempat. Yogyakarta : BPFE

Suryadi, Ace. 1994. "Hubungan Antara Pendidikan, Ekonomi dan Pengangguran Tenaga Terdidik”. Prisma No.8 Tahun XXIII Agustus

Tarigan, Robinson. 2004. Ekonomi Regional : Teori dan Aplikasi. Jakarta : Bumi Aksara

Todaro, Michael P. 2000. Pembangunan Ekonomi di Dunia Ketiga. Edisi kelima. Surabaya : 